\title{
KONFLIKTY BENEDYKTYNÓW JEŻOWSKICH Z OPATAMI LUBIŃSKIMI W XV I XVI WIEKU W ŚWIETLE KRONIKI KLASZTORNEJ BARTŁOMIEJA Z KRZYWINIA
}

\section{Wprowadzenie}

Początki monastycyzmu benedyktyńskiego na Mazowszu skrywają wciąż wiele tajemnic. $\mathrm{Z}$ pewnym prawdopodobieństwem możemy stwierdzić już w pierwszej połowie XII w. przejściową jedynie obecności czarnych mnichów we Włocławku i utworzenie tam prepozytury opactwa mogileńskiego, usytuowanej przy kościele parafialnym św. Jana Chrzciciela $^{1}$. Nieco później miała miejsce fundacja kościoła i hospicjum św. Gotarda w Szpetalu, położonego naprzeciw grodu we Włocławku, którą także łączy się z benedyktynami z Mogilna². Z kolei pierwsze opactwo pod wezwaniem św. Wojciecha w Płocku powstało najpewniej dopiero w drugiej połowie XII w., jego pomysłodawcami byli książę Bolesław Kędzierzawy oraz biskup Werner ${ }^{3}$. Z tego okresu pochodzi również najprawdopodobniej ostatnia z XII-wiecznych fundacji benedyktyńskich na ziemiach polskich, a mianowicie prepozytura w Jeżowie. Słabo uposażona placówka, nieciesząca się zainteresowaniem panujących oraz niewykazująca dużej aktywności gospodar-

\footnotetext{
${ }^{1}$ J. P ł o c h a, Najdawniejsze dzieje benedyktynów z Mogilna, Wrocław-WarszawaKraków 1969, s. 86; G. L a b u d a, Początki klasztoru w świetle źródel pisanych, [w:] Materiały sprawozdawcze, z. 1, 1978, s. 35; M. D e rw i c h, Monastycyzm benedyktyński w średniowiecznej Europie i Polsce. Wybrane problemy, Wrocław 1998, s. 190-191.

${ }^{2}$ M. D e r w i c h, dz. cyt., s. 191-192.

${ }^{3}$ K. P a c u s k i, Początki benedyktyńskiego opactwa św. Wojciecha na grodzie płockim, Społeczeństwo Polski średniowiecznej, red. S. K. K u c z y ń s k i, t. 5, Warszawa 1992, s. 135-140; M. D e r w i c h, dz. cyt., s. 195-196.
}

„Nasza Przeszłość” t. 132: 2019, s. 53-65. 
czej i kulturalnej, nie odegrała znaczącej roli na Mazowszu. Fakt ten sprawił niestety, że dzieje benedyktynów jeżowskich nie przyciągnęły uwagi historyków. Badania przynoszą ustalenia głównie w zakresie początków klasztoru w Jeżowie, pomijając inne ważne aspekty, jak chociażby wątek konfliktów $\mathrm{z}$ opactwem lubińskim podejmowany w tej pracy ${ }^{4}$.

\section{Stan prawny prepozytury jeżowskiej}

Prepozytura nie charakteryzowała się suwerennością, a co za tym idzie nie posiadała osobowości prawnej. Ta należała wyłącznie do opactwa macierzystego w Lubiniu. Zasady kontaktów prepozytury jeżowskiej z opactwem w Lubiniu znane są nam dopiero z przekazów XVI-wiecznych. Wynika z nich, że opat lubiński posiadał pełnię władzy nad prepozytem, a tym samym całym konwentem z Jeżowa 5 . Warto dodać, że określenie mnisi jeżowscy, ma wyłącznie znaczenie geograficzne. De facto byli oni mnichami lubińskimi, tam składali profesję, zaś do Jeżowa wysyłani byli przez opatów w celu zarządza-

${ }^{4}$ Badacze są zgodni, iż fundacja miała miejsce w XII w. Wciąż nierozstrzygnięte pozostają pytania o dokładniejszą datację oraz osobę, bądź osoby fundatorów. Niepewny jest także status klasztoru w momencie fundacji. Zob. Liber fraternitatis Lubiniensis, wyd. F. P a pe e, [w:] Monumenta Poloniae Historica, t. 5, Lwów 1888, s. 566-567; Liber mortuorum Lubiniensis ordinis Sancti Benedicti, wyd. W. K ętrzyńs ki, [w:] Monumenta Poloniae Historica, t. 5, Lwów 1888, s. 585-652; W. A b r a h a m, Organizacja kościoła $w$ Polsce do połowy XII w., Lwów 1893, s. 177; W. S e m k o w i c z, Ród Awdańców w wiekach średnich, [w:] Roczniki Poznańskiego Towarzystwa Przyjaciół Nauk, 45, 1919, s. 227-228; Z. P e r z a n o w s k i, Honorarium autorskie Galla-Anonima, „Nasza Przeszłość” (dalej: NP), 9, 1959, s. 19-37; T e n ż e, Opactwo benedyktyńskie w Lubiniu. Studia nad fundacja i rozwojem uposażenia $w$ średniowieczu, Wrocław 1978; M. C e t w i ń s k i, Jeszcze o fundacji opactwa benedyktynów w Lubiniu, Sobótka, (36), 1981, s. 463; J. B i e n i a k, Polska elita polityczna XII w., część. III. A. Arbitrzy książą-Krąg rodzinny Piotra Włostowica, Społeczeństwo Polski średniowiecznej, red. S. K. K u c z y ń s ki, t. 4, Warszawa 1990, s. 42-43; J. U r b a n, Prepozytury opactwa benedyktynów w Lubiniu w XVI w. „Zeszyty Lubińskie” (dalej: ZL), 1995, z. 4, s. 27-41; M. D e r w i c h, dz. cyt., s. 196-197; J. D o bos z, Monarchia i możni wobec Kościoła $w$ Polsce do początku XIII w., Poznań 2002, s. 255.

${ }^{5}$ APP, Wypisy z ksiąg klasztornych, różnych kronik i dokumentów, sygn.: 237 (dalej: APP). W kronice Bartłomieja z Krzywinia natrafiamy na rozstrzygający passus: „...Praepositus, et suis succesores in Jezevo; ex tunc in antea obedientia monachali praefato Abbati et vobis Conventus, ac alis pro tempore existentibu:s Abbatibus praedicta Monasterii Lubiniensi obeodiret...”. APP, sygn. 235. 
nia majątkiem (zarówno ruchomym, jak i nieruchomym) i prowadzić tamtejszą parafię ${ }^{6}$. Nominacja na urząd prepozyta pozostawała w gestii opata lubińskiego oraz najpewniej kapituły, która dysponowała jedynie głosem doradczym ${ }^{7}$. Istotny wpływ na kształtowanie relacji wewnątrz konwentów wywierali hierarchowie diecezjalni. Należy pamiętać bowiem, że zakon benedyktynów na ziemiach polskich nie cieszył się przywilejem egzempcji, co oznaczało, że znajdował się pod władzą biskupią ${ }^{8}$. W praktyce biskupi mieli prawo wizytować klasztory, roztaczać nad nimi ogólny nadzór, a także za pomocą kar przywoływać do porządku nieposłusznych mnichów ${ }^{9}$. W przypadku Jeżowa władzę tę sprawował arcybiskup gnieźnieński i to on dokonywał ostatecznego zatwierdzenia, informując w specjalnym dokumencie o udzielonej kandydatowi inwestyturze ${ }^{10}$. Opat nie mógł swobodnie usuwać niewygodnego prepozyta, ponieważ zobowiązany był przedłożyć arcybiskupowi zastrzeżenia do jego osoby. Ostateczna decyzja znajdowała się znowu w rękach biskupa. ${ }^{11}$. Opaci lubińscy dość swobodnie mogli natomiast kreować oblicze ekonomiczne podległej im prepozytury. Wiele decyzji gospodarczych wymagało ich zgody lub przynajmniej konsultacji ${ }^{12}$. To generowało liczne problemy, ponieważ prepozyci nie zawsze realizowali wytyczne swoich lubińskich przełożonych, zaś decyzje, które podejmowali sytuowały się w opozycji do planów przyjętych w Lubiniu.

\section{Dzieje konfliktów w XV i XVI wieku}

U schyłku średniowiecza benedyktyni jeżowscy podjęli pierwsze znane próby zmierzające do likwidacji niektórych obciążeń na rzecz

\footnotetext{
${ }^{6}$ APP, Metryka profesów opactwa lubińskiego, sygn. 238.

7 APP, sygn. 237. Por. M. T. Gro n o w s k i Zwyczajny klasztor, zwyczajni mnisi. Wspólnota tyniecka $w$ średniowieczu, Kraków 2007, s. 94.

${ }^{8}$ F. B o g d a n, Sprawa wyjęcia polskich benedyktynów spod władzy biskupiej $w$ epoce przedtrydenckiej. Studium historyczno-prawne, „Sacrum Poloniae Millenium”, t. 10, Rzym 1964, s. 19-40.

${ }^{9}$ F. B o g d a n, Spraw egzempcji benedyktynów $w$ Polsce średniowiecznej, NP, 9, 1959, s. 58.

${ }^{10}$ APP, sygn.: 237.

11 Kodeks dyplomatyczny Wielkopolski, t. 5, wyd. F. Pi ek os ińs ki, Poznań 1878/1881, nr 603 (dalej: KDW).

12 Archiwum Archidiecezjalne w Łodzi, Akta dekanatu brzezińskiego, sygn. 104 (dalej: AAŁ).
} 
opactwa. Tego typu działaniom sprzyjać mogła stabilna sytuacja materialna ${ }^{13}$ prepozytury oraz autorytet jakim cieszyli się prepozyci jeżowscy ${ }^{14}$. Czynniki te, w oczywisty sposób budujące pozycję prepozytów jeżowskich, mogły skłonić niektórych z nich do większej samodzielności, sprawić, że objąwszy ten zaszczytny urząd działali z punktu widzenia interesów Lubinia zbyt autonomicznie.

Okoliczności konfliktów, poznajemy dzięki XVII-wiecznemu dziejopisowi klasztornemu Bartłomiejowi z Krzywinia ${ }^{15}$. Swoją kronikę pisał Krzywiński na podstawie takich źródeł jak: listy stron konfliktu (opatów i prepozytów), bulle papieskie oraz dokumentacja pochodząca z kurii arcybiskupstwa gnieźnieńskiego. Te dwa ostatnie typy źródeł stanowiły ważne rozstrzygnięcia formalno-prawne interesującego nas sporu. Zebrany $\mathrm{w}$ ten sposób materiał, dziejopis miał w zwyczaju

13 Benedyktyni jeżowscy mieli bowiem w tym okresie pod swoim zarządem dość spory majątek. W tym miejscu warto wymienić, że byli w posiadaniu Jeżowa, który był wówczas miastem klasztornym oraz pięciu wsi: Jasienina, Mikulina, Góry, Przyłęku i Krosnowej. APP, sygn. 237.

${ }^{14}$ Spośród 48 znanych nam prepozytów, aż 10 dostąpiło godności opackiej. W interesującym nas okresie, a więc na przełomie XV i XVI w., 3 prepozytów pełniło urząd opata. Jak bardzo mnisi cenili sobie urząd prepozyta doskonale ilustruje przykład Floriana Balickiego, który po wyborze na przeora w Lubiniu w 1761 r. nie zamierzał zrzec się funkcji prepozyta. APP, sygn. 238. Rację miał M. Kanior pisząc, że w precedencji lubińskiej prepozyci jeżowscy szli bezpośrednio po przeorze. Zob. T e n ż e, Polska Kongregacja Świętego Krzyża 1709-1864, Kraków 2000, s. 103. Jak bardzo mnisi cenili sobie urząd prepozyt potwierdzają także przykłady płynące z Tyńca. Zob. T. M. Gron o w s k i, op. cit., s. 97.

${ }^{15}$ Dziejopis lubiński urodził się w końcu XVI w. w Krzywiniu, mieście należącym do opactwa. W 1608 r. złożył uroczyste śluby zakonne w klasztorze lubińskim, gdzie zmarł w 1667 r., przeżywszy w zakonie 61 lat. Pracę nad kroniką przerwał raptownie 12 sierpnia 1655 r., prawdopodobnie w związku z najazdem wojsk Karola Gustawa. Ostatni wpis zakończył na roku 1630, tj. śmierci Eustachego Wołłowicza, biskupa wileńskiego i opata komendatoryjnego w Lubiniu. Kronikę spisał najpewniej w połowie XVII w., opierając się głównie na zbiorach archiwalnych opactwa lubińskiego oraz dokonaniach wielkiego poprzednika - Tomasza ze Zbrudzewa, którego wspomina jedynie lapidarnie. Zob. P. S c z a n i e c k i, Bartłomiej z Krzywinia, [w:] Encyklopedia Katolicka, t. 2, Lublin 1976, k. 78; B. U r b an, Bartłomiej z Krzywinia i jego kronika, ZL, z. 3, 1994, s. 22; A. J e z i e r s k i, Klasztor Benedyktynów w Lubiniu, Poznań 1915, s. 38; M. C h w a 1 i s z e w s k i, Żywot $i$ cuda wielebnego stugi o. Bernarda z Wąbrzeźna, Poznań 1881, s. 202-203; I. K w i 1 e c k a, Nieznany pisarz wielkopolski Tomasz Łysy z Zbrudzewa, [w:] Munera Posnaniensia. Księga pamiatkowa UAM w Poznaniu dla uczczenia 600-lecia założenia Uniwersytetu Jagiellońskiego, red. G. L a b u d a, Poznań 1965, s. 220. 
wciągać in exstenso do swojej kroniki. Jego przekaz pozbawiony jest zabarwienia emocjonalnego, zbędnych gloss. Kronikarz skoncentrowany jest przede wszystkim na samych wydarzeniach i ich przebiegu, nie zaś ocenach. Jest to jednak jedyne istniejące źródło relacjonujące tamte wydarzenia ${ }^{16}$. To na jego podstawie możemy przyjrzeć się dynamice konfliktu, dociekać motywacji zwaśnionych stron, rozświetlić problematykę skutków, zarówno krótko, jak i długofalowych.

Pierwszy konflikt, o którym pisze Krzywiński miał miejsce w 1437 r., jego przedmiotem była danina sukna, którą wnosili mnisi jeżowscy na rzecz Lubinia. Sprawa znalazła swój finał przed trybunałem arcybiskupa gnieźnieńskiego, który potwierdził obowiązek dostarczania sukna na habity, spoczywający na prepozycie Klemensie oraz jego następcach ${ }^{17}$. Podjęta decyzja nie rozwiązała jednak sprawy, albowiem spór wybuchał jeszcze dwukrotnie w 1448 i 1472 r. ${ }^{18}$, ponownie kończąc się niekorzystnym orzeczeniem dla prepozytury. Konsekwencje odmawiania daniny sukna nie miały wyłącznie natury materialnej. Z relacji Krzywińskiego wynika, że w 1510 r. prepozyt Piotr na mocy decyzji opata Macieja z Miechorzewa został wykluczony z mniszej wspólnoty ${ }^{19}$. Samo wykluczenie niosło poważne konsekwencje, zarówno osobiste, jak i prawne. W istotny sposób komplikowało położenie prepozyta Piotra w Jeżowie, zwłaszcza w relacji z przebywającymi tam mnichami oraz w środowisku poza klasztornymi murami. W kronice Krzywińskiego czytamy, że Piotr stawił się przed arcybiskupem gnieźnieńskim, skarżąc się na decyzje opata Macieja. Arcybiskup wystosował pismo do opata, w którym podkreślił nieadekwatność podjętych przez niego środków. Ostatecznie opat przywrócił prepozyta Piotra do wspólnoty,

\footnotetext{
16 Pisząc swoją kronikę Krzywiński czerpał z dzieła mnicha lubińskiego Tomasz ze Zbrudzewa który przebywał w klasztorze w XVI w. Niestety źródło to nie zachowało się do naszych czasów. Zob. B. U r b a n, dz. cyt., s. 22.

17 Celemens modernus prepositis in Ieszewo et sui succesores quolibet anno in festo sancti Martini confesoris, racione huiusmodi subieccionis tenentur et sunt astricti dare pro fratribus in Lubyn duo stamina de harrassio pro cuculis... dominium Clementem prepositum et successores suos cogimus et compelimus ac condempnamus per presentes, quod huiusmodi duo stamina harressi solvebantur per anteccessores conventui Lubyn. KDW, t. 5, nr 603.

18 Dokumenty opactwa benedyktynów w Lubiniu z XII-XV wieku, wyd. Z. P e r z a n o w s k i (KDW, s. n., 1), Warszawa-Poznań 1975., nr 221 (dalej: DL), nr 293.

${ }^{19}$ APP, sygn. 235.
} 
zastrzegając konieczność ponoszenia zwyczajowych świadczeń ${ }^{20}$. Decyzja opata Macieja o wykluczeniu prepozyta jest pierwszą tego typu, która ma swoje odbicie w znanym materiale źródłowym. Roboczo można uznać ją za swoisty precedens. Kolejni opaci - jak wykażę dalej - w obliczu rodzącego się konfliktu z prepozytami będą często sięgać po wykluczenie ze wspólnoty chcąc w ten właśnie sposób przywołać do posłuszeństwa swoich podwładnych.

W 1528 r. obejmujący urząd prepozyta jeżowskiego Mikołaj Wyleziński został ekstraordynaryjnie zwolniony z płacenia daniny 6 grzywien $^{21}$. Jego następca - Paweł Chojnacki, podjął starania, aby zwolnienie dotyczyło także jego osoby. Opat lubiński nie wyraził jednak na to swojej zgody, co w konsekwencji doprowadziło do kolejnego napięcia na linii Lubiń - Jeżów. Konflikt nabrał szczególnego wymiaru, kiedy to opat osadził krnąbrnego prepozyta w karcerze. Według Bartłomieja z Krzywinia sprawa znalazła swój finał w Stolicy Apostolskiej $^{22}$. Papież Klemens VII nakazał wówczas opatowi oraz jego następcom, osobistą kontrolę nad prepozyturą, a w razie trudności wyznaczenie specjalnej komisji składającej się z dwóch mnichów, których obowiązkiem było sporządzenie specjalnego raportu po dokonaniu wizytacji. Ponadto prepozyci zobowiązani zostali do składania przed kapitułą sprawozdań finansowych ze swojej działalności. Wedle nowych ustaleń mogli zatrzymać zaledwie 12 grzywien $\mathrm{z}$ dochodu prepozytury, natomiast pozostałą część musieli przekazać opactwu ${ }^{23}$. Możemy z całą mocą stwierdzić, że decyzje papieskie przyjęły się, ponieważ znajdują swoje odzwierciedlenie w kolejnych przekazach źródłowych już XVII-wiecznych ${ }^{24}$.

Z uchwał kapituły lubińskiej z 1541 r. możemy wnosić, iż kondycja finansowa prepozytury była zadowalająca, skoro w Lubiniu zadecydowano o nałożeniu na prepozyturę (z dóbr klasztornych) stałej sumy w wysokości 8 złotych węgierskich wraz z nadwyżką dochodów. Rygory te stały się zarzewiem nowego konfliktu, ponieważ w $1553 \mathrm{r}$. prepozyt Wojciech z Mszczonowa podjął próbę uchylenia się od kłopotliwych zobowiązań. Napięcie pogłębiał fakt, iż prepozyt nie złożył

\footnotetext{
${ }^{20}$ APP, sygn. 235.

${ }^{21}$ APP, sygn. 235.

22 APP, sygn. 235.

${ }^{23}$ APP, sygn. 235.

${ }^{24}$ APP, sygn. 237.
} 
sprawozdania finansowego, do którego był zobowiązany. Decydujący musiał być jednak fakt, iż do klasztoru jeżowskiego nie zostali przyjęci dwaj mnisi (nominaci opata), którzy mieli pełnić tam funkcję wikariuszy ${ }^{25}$. Z kroniki Krzywińskiego wynika ponadto, że prepozyt kontaktował się $\mathrm{z}$ arcybiskupem gnieźnieńskim prosząc, aby ten wsparł go w sporze $\mathrm{z}$ opatem. Reakcja Lubinia była zdecydowana. Na zwołanej kapitule postanowiono (nie po raz pierwszy), że niezdyscyplinowany prepozyt zostanie wyłączony ze wspólnoty mniszej. Prepozyt Wojciech, korzystając zapewne z doświadczeń poprzedników, nie czekał na rozwój sytuacji i udał się wprost do arcybiskupa gnieźnieńskiego z prośbą o wstawiennictwo, uzyskując ostatecznie dekret potępiający roszczenia opata. Konflikt znacznie się zaostrzył, kiedy arcybiskup, oparłszy się na nieprawdziwej pogłosce, oskarżył opata Chojnackiego o zlecenie zabójstwa prepozyta ${ }^{26}$ i polecił jego bezzwłoczne pochwycenie ${ }^{27}$. W odpowiedzi na zdecydowane działania arcybiskupa, opat lubiński interweniował u Piusa IV. Papież ponownie wydał decyzję korzystną dla opata, przyznając mu 8 złotych z prepozytury oraz czynsz zbożowy od mieszczan jeżowskich ${ }^{28}$. W bulli papież stwierdza, że prepozyci swym postepowaniem nie tylko naruszają fundamentalne zasady benedyktyńskie, wywiedzione z reguły św. Benedykta, które każą być posłusznym opatom, ale prowadzą działania, które w Stolicy Apostolskiej odczytywane były jako niczym nieuzasadniona próba osiągnięcia niezależności ${ }^{29}$. Ciekawe,

25 Środki podjęte przez mnichów jeżowskich nie były niczym wyjątkowym. Oto w 1526 r. do klasztoru w Tuchowie nie został wpuszczony przez współbraci legalnie wybrany prepozyt - Stanisław Buchcicki. Zob. M. T. G r o n o w s k i, dz. cyt., s. 97.

${ }^{26}$ APP, sygn.: 235. Podobnie dramatyczne wydarzenia miały miejsce w przypadku opactw cysterskich w Rudach i Jemielnicy. W 1558 r. podczas pobytu w Opolu zmarł nagle, po wypiciu pucharu wina, opat rudzki Leonard. Goszczącemu go wówczas opatowi jemielnickiemu Janowi, postawiono zarzut otrucia. Tłem dla tego zdarzenia był znacznie poważniejszy i ciągnący się między dwoma opactwami spór o tzw. ius paternitatis. Zob. M. L. W ó j c i k, Rozbrat Jemielnicy z Rudami. Ze studiów nad wzajemnymi relacjami górnośląskich cysterskich, [w:] Klasztor w Kościele średniowiecznym i nowożytnym, red. M. D e r w i c h, A. P o b ó g - L e n a r t o w i c z, Warszawa-Wrocław-Opole 2010, s. 409-427.

27 APP, sygn. 235.

28 APP, sygn. 235.

${ }^{29}$ W bulli, którą cytuje Krzywiński odnajdujemy interesujący nas passus nt. prepozyta i jego postępowania, ...praepositiis qui autem voluerunt facere non solum inobediens est independens (podkr. autora)...".APP, sygn.: 235. Użycie słowa independes 
że tak jednoznacznie odczytano intencje prepozyta właśnie w Rzymie. W zbadanych przeze mnie materiale źródłowym, który wyekscerpowano w Lubiniu, czy w Gnieźnie, próżno szukać tego typu określeń. Sam Krzywiński nigdzie na kartach swojej kroniki nie formułuje tak jednoznacznej oceny postępowania prepozytów. Być może użycie mocnego sformułowania przez Watykan miało charakter prewencyjny, zabezpieczający przed dalszą ewentualną eskalacją konfliktu.

Rekonstrukcję wypadków następujących po wydaniu bulli z 1553 r., komplikuje fakt milczenia źródeł. Sam lubiński kronikarz wie w tej sprawie raczej niewiele. Pisze, że w 1563 r. Wojciech z Mszczonowa złożył przysięgę wierności opatowi, zaś w Lubiniu podjęto decyzję o nałożeniu kary finansowej w wysokości tysiąca florenów na kolejnych buntujących się prepozytów ${ }^{30}$. Ta skądinąd ciekawa informacja źródłowa rozszerzająca naszą wiedzę nt. rygorów, którymi chciano dyscyplinować zbyt samodzielnych prepozytów, nie pozwala rozstrzygnąć, czy sam konflikt zakończył się po wydaniu bulli, czy też trwał jeszcze całą dekadę, aż do 1563 r. Sądzę, że jest mało prawdopodobne, aby toczący się przez następne lata spór (po 1553 r.) nie przyniósł nowych rozstrzygnięć. Te zapewne odnotowałby w swoim dziele, bardzo skrupulatny przecież, Krzywiński. Nie możemy wykluczyć, że złożenie przysięgi w 1563 r. nie musiało mieć bezpośredniego związku z konfliktem, który zainicjował prepozyt Wojciech, podobnie jak decyzja kapituły w sprawie ekstraordynaryjnego obciążenia. Spiętrzenie hipotez, nie czyni moich ustaleń pewnymi, stąd na podstawie źródeł mogę stwierdzić z całą pewnością jedynie to, że kary finansowe nie były na tyle odstraszające, aby powstrzymać od nieposłuszeństwa. Oto bowiem w 1594 r. prepozyt Grzegorz Stolecki ponownie odmówił płacenia należnego opactwu czynszu. W kronice czytamy, że opat interweniował u arcybiskupa, skarżąc się, iż prepozyt naraża na szwank dobre imię wspólnoty lubińskiej. W rezultacie ordynariusz gnieźnieński zdecydował się powołać specjalną komisję, która na miejscu miała zbadać sprawę ${ }^{31}$. Nie wiemy, czy komisja dotarła do Jeżowa i czy jej członkowie sporządzili raport ze swojej

w sposób wyraźny prowadzi do odczytania go jako: niezależny, bądź niezawisły. Zob. Słownik łaciny średniowiecznej w Polsce, red. M. Plezi a, t. 5, WrocławWarszawa-Kraków-Gdańsk-Łódź, s. 413.

${ }^{30}$ APP, sygn. 235.

${ }^{31}$ APP, sygn. 235. 
kontroli, chociaż jest to wielce prawdopodobne. Pewne jest natomiast to, że w 1594 r. kapituła uznała prepozyta winnym. Wymuszone na prepozycie przyznanie się do wszelkich przewin, skutkowało dodatkowo nałożeniem czynszu w wysokości 100 złotych węgierskich, które odtąd mieli ponosić także jego następcy ${ }^{32}$.

Z przytoczonych wyżej przykładów wynika niezbicie, że stronami konfliktów, a często ich inicjatorami, byli prepozyci. Jest to jak najbardziej zrozumiałe, ponieważ to oni kierowali placówką duchowną i byli za nią odpowiedzialni. Ciekawym przykładem, wymykającym się z tej charakterystyki są wypadki z 1578 r. Wówczas to prepozytem został Stanisław Kiszewski h. Nałęcz. Jego wybór był kwestionowany przez przebywających w Jeżowie mnichów. Ich zdaniem Kiszewski nie miał prawa objąć funkcji prepozyta, ponieważ nie ukończył jeszcze nowicjatu. W sprawę zaangażował się ordynariusz gnieźnieński, który polecił opatowi (wcześniejszemu prepozytowi jeżowskiemu), aby Kiszewski dopełnił nowicjatu, a następnie objął urząd prepozyta ${ }^{33}$. W końcu został on prepozytem i pełnił tę funkcję do $1588 \mathrm{r}$. kiedy to kapituła lubińska obrał go opatem.

\section{Podsumowanie}

Ostatecznie próby zrzucenia niektórych ciężarów (np. daniny sukna) podejmowane przez prepozytów jeżowskich w XV i XVI w. zakończyły się niepowodzeniem i doprowadziły do jeszcze większego zbliżenia i ugruntowania wzajemnych zależności, czego dobitnym świadectwem są decyzje kapituły lubińskiej z lat $15941595^{34}$. Wypracowane wówczas rozwiązania formalno-prawne okazały się być bardzo trwałe, ponieważ w późniejszym okresie, nie dochodziło już do tak gwałtownych konfliktów między prepozyturą a opactwem lubińskim. Nie wydaje się zasadne stanowisko Jacka Urbana, według którego u podłoża aktywności prepozytów znajdowały się dążenia separatystyczne, których celem miał być projekt zmiany statusu prepozytury na w pełni samo-

\footnotetext{
32 APP, sygn. 235.

33 APP, sygn. 235.

34 Pośród najważniejszych decyzji wymieńmy przede wszystkim: absolutne posłuszeństwo wobec opatów, czy bardziej konkretne jak np. obowiązek składania sprawozdań finansowych i karne stawianie się w Lubiniu. Biblioteka Jagiellońska, Oddział Starych Druków, sygn. 3544.
} 
dzielny klasztor ${ }^{35}$. Analiza źródeł nie pozwala na tak mocną konstatację. Próżno doszukiwać się w nich informacji, iż działania prepozytów podszyte były chęcią emancypacji, całkowitego wyzwolenia spod władzy Lubinia. W mojej opinii decyzje podejmowane przez prepozytów związane były przede wszystkim ze sprawami materialnymi (np. wysokością czynszu). Tym samym nie wychodziły poza obszar ekonomiki klasztornej i co najwyżej dotyczyły odmiennej wizji określonych zobowiązań na rzecz Lubinia. W interesującym nas okresie prepozyci wciąż uczestniczą w posiedzeniach kapituły, do Lubinia dość regularnie spływają sprawozdania finansowe ${ }^{36}$ oraz należne daniny ${ }^{37}$. Pełny obraz stosunków pomiędzy Jeżowem a Lubiniem na przestrzeni XV i XVI w. jest jak najbardziej pozytywny. W tym świetle, odczytanie działań prepozytów jako separatystycznych, wydaje być nadinterpretacją. Pomimo dramatycznych wydarzeń, skomplikowanych relacji prepozytów i opatów ${ }^{38}$ - to jednak efektywna współpraca będzie charakteryzowała wzajemnie stosunki w tym okresie ${ }^{39}$.

${ }^{35} \mathrm{~J}$. U r b a n, $d z$. cyt., s. 29-34.

${ }^{36}$ Wiemy od Krzywińskiego, że spod tego rygoru wyłamał się 1553 r. prepozyt Wojciech z Mszczonowa. APP, sygn. 235.

${ }^{37}$ APP, sygn. 237.

${ }^{38}$ Nie chcąc nadmiernie psychologizować zauważmy, że wpływ na budowanie relacji mógł mieć także czynnik indywidualny. Silne osobowości często utrudniały poszukiwania wspólnych rozwiązań. Kompromis w rzeczywistości, w której funkcjonowały opactwo i prepozytura był niemożliwy. Każdy bowiem sprzeciw ze strony prepozytów mógł być odczytany w Lubiniu, tylko w jeden sposób - jako przejaw nieposłuszeństwa.

39 Trudno w tym miejscu przywołać wszystkie przykłady współpracy na linii Lubiń Jeżów w badanym okresie. Pośród wielu na pierwszy plan w oczywisty sposób wysuwa się najpoważniejsza wspólna inwestycja z połowy XVI w. polegająca na przebudowie kościoła w Jeżowie oraz reorganizacja domeny ziemskiej, która zwiększyła wydajność gospodarki klasztornej. APP, sygn. 237. 


\section{Bibliografia}

\section{Źródla rękopiśmienne}

Archiwum Państwowe w Poznaniu:

Bartłomiej z Krzywinia, Antiquitatum Monasterii OSB libri duo, sygn. 235.

Wypisy z ksiąg klasztornych, różnych kronik i dokumentów, sygn. 237.

Metryka profesów opactwa lubińskiego, sygn. 238.

Archiwum Archidiecezjalne w Lodzi:

Akta dekanatu brzezińskiego, sygn. 104.

Biblioteka Jagiellońska:

Oddział Starych Druków, sygn. 3544.

\section{Źródła drukowane}

Kodeks dyplomatyczny Wielkopolski, t. 5, wyd. F. Piekosiński, Poznań 1878-1881.

Dokumenty opactwa benedyktynów w Lubiniu z XII-XV wieku, wyd. Z. Perzanowski (KDW, s. n., 1), Warszawa-Poznań 1975.

\section{Literatura}

\section{Opracowania}

W. Abraham, Organizacja kościoła w Polsce do połowy XII w., Lwów 1893.

J. Bieniak, Polska elita polityczna XII w., Część. III. A. Arbitrzy ksiażat-Krag rodzinny Piotra Włostowica, Społeczeństwo Polski średniowiecznej, red. S. K. Kuczyński, t. 4, Warszawa 1990, s. 13-74.

F. Bogdan, Sprawa wyjęcia polskich benedyktynów spod władzy biskupiej w epoce przedtrydenckiej. Studium historyczno-prawne, Sacrum Poloniae Millenium, t. 10, Rzym 1964, s. 19-40.

M. Chwaliszewski, Żywot i cuda wielebnego stugi o. Bernarda z Wąbrzeźna, Poznań 1881.

M. Derwich, Monastycyzm benedyktyński w średniowiecznej Europie i Polsce. Wybrane problemy, Wrocław 1998.

J. Dobosz, Monarchia i możni wobec Kościoła w Polsce do początku XIII w., Poznań 2002.

M. T. Gronowski, Zwyczajni klasztor, zwyczajni mnisi. Wspólnota tyniecka w średniowieczu, Kraków 2007.

M. Kanior, Polska Kongregacja Świętego Krzyża 1709-1864, Kraków 2000.

I. Kwilecka, Nieznany pisarz wielkopolski Tomasz Łysy z Zbrudzewa, [w:] Munera Posnaniensia. Ksiegga pamiatkowa UAM w Poznaniu dla uczczenia 600-lecia założenia Uniwersytetu Jagiellońskiego, red. G. Labuda, Poznań 1965, s. 220. 
Liber fraternitatis Lubiniensis, wyd. F. Papee, [w:] Monumenta Poloniae Historica, t. 5, Lwów 1888, s. 566-567.

Liber mortuorum Lubiniensis ordinis Sancti Benedicti, wyd. W. Kętrzyński, [w:] Monumenta Poloniae Historica, t. 5, Lwów 1888, s. 585-652.

K. Pacuski, Początki benedyktyńskiego opactwa św. Wojciecha na grodzie płockim, Społeczeństwo Polski średniowiecznej, red. S. K. Kuczyński, t. 5, Warszawa 1992, s. 135-152.

Z. Perzanowski, Opactwo benedyktyńskie w Lubiniu. Studia nad fundacja i rozwojem uposażenia w średniowieczu, Wrocław 1978.

J. Płocha, Najdawniejsze dzieje benedyktynów z Mogilna, Wrocław-Warszawa-Kraków 1969.

P. Sczaniecki, Bartlomiej z Krzywinia, Encyklopedia katolicka, t. 2, Lublin 1976, kol. 78-79. W. Semkowicz, Ród Awdańców w wiekach średnich, [w:] Roczniki Poznańskiego Towarzystwa Przyjaciół Nauk, (45), 1919, s. 161-314.

M. L. Wójcik, Rozbrat Jemielnicy z Rudami. Ze studiów nad wzajemnymi relacjami górnoślaskich cysterskich, [w:] Klasztor w Kościele średniowiecznym i nowożytnym, red. M. Derwich, A. Pobóg-Lenartowicz, Warszawa-Wrocław-Opole 2010, s. 409-427.

\section{Czasopisma}

F. Bogdan, Sprawa egzempcji benedyktynów w Polsce średniowiecznej, „Nasza Przeszłość”, 9, 1959, 51-89.

M. Cetwiński, Jeszcze o fundacji opactwa benedyktynów w Lubiniu, „Sobótka”, (36), 1981, s. 455-463.

G. Labuda, Początki klasztoru $w$ świetle źródet pisanych, [w:] Materiały sprawozdawcze, z. 1, 1978, s. 1-59.

Z. Perzanowski, Honorarium autorskie Galla-Anonima, „Nasza Przeszłość”, (9), 1959, s. 19-37.

B. Urban, Bartłomiej z Krzywinia i jego kronika, „Zeszyty Lubińskie”, z. 3, s. $22-25$.

J. Urban, Prepozytury opactwa benedyktynów w Lubiniu w XVI w., „Zeszyty Lubińskie", 1995, s. 27-41.

\section{Słowniki}

Słownik łaciny średniowiecznej w Polsce, red. M. Plezia, t. 5, WrocławWarszawa-Kraków-Gdańsk-Łódź 1978-1984. 
ŁUKASZ KĄŚS

\title{
KONFLIKTY BENEDYKTYNÓW JEŻOWSKICH \\ Z OPATAMI LUBIŃSKIMI W XV I XVI WIEKU \\ W ŚWIETLE KRONIKI KLASZTORNEJ \\ BARTLOMIEJA Z KRZYWINIA
}

Streszczenie: Jeżów to ostatnia z XII-wiecznych fundacji benedyktyńskich na ziemiach polskich. Klasztor od początku pomyślany został jako prepozyturą opactwa benedyktynów w Lubiniu. U schyłku średniowiecza benedyktyni jeżowscy podjęli pierwsze próby zmierzające do likwidacji niektórych obciążeń na rzecz opactwa. Okoliczności sporów, poznajemy dzięki XVII-wiecznemu dziejopisowi klasztornemu Bartłomiejowi z Krzywinia. Jego kronika jest wiarygodnym źródłem, dzięki któremu możemy przyjrzeć się dynamice konfliktów, mechanizmom ich przebiegu, rozświetlić problematykę skutków, zarówno krótko, jak i długofalowych. Ostatecznie próby zrzucenia niektórych ciężarów (np. daniny sukna) podejmowane przez benedyktynów jeżowskich w XV i XVI w. zakończyły się niepowodzeniem i doprowadziły w konsekwencji do jeszcze większego zbliżenia prepozytury z opactwem w Lubiniu. Wypracowane wówczas rozwiązania formalno-prawne, wprowadzone później oficjalnie do statutów kapituły lubińskiej, okazały się być bardzo trwałe, ponieważ w późniejszym okresie, nie dochodziło już do tak gwałtownych i głębokich konfliktów.

Słowa kluczowe: mnisi, opactwo, prepozytura.

\section{CONFLITS OF BENEDICTINES FROM JEŻÓW WITH THE ABBOTS OF LUBIŃ IN THE $15^{\mathrm{TH}}$ AND $16^{\mathrm{TH}}$ CENTURY IN THE LIGHT OF THE CHRONICLE OF BARTHOLOMAEUS CRIVINIUS [BARTLOMIEJ Z KRZYWINIA]}

\begin{abstract}
Jeżów is the last of the $12^{\text {th }}$-century Benedictine foundations in Poland. From the very beginning, the monastery was conceived as a prepositure of the Benedictine Abbey in Lubiń. In the late Middle Ages, the Benedictines of Jeżów made the first attempts to eliminate some financial burdens towards the abbey. The circumstances of the conflict are known thanks to the $17^{\text {th }}$ century monastery chronicler Bartholomaeus Crivinius. His chronicle is a reliable source, thanks to which we can look at the dynamics of conflicts and the mechanisms of their course as well as cast some light on the short and long term effects. Ultimately, the attempts to avoid financial burdens made in the $15^{\text {th }}$ and $16^{\text {th }}$ centuries ended in failure and, as a consequence, led to even greater rapprochement. The formal and legal solutions developed at that time, later officially introduced into the statutes of the Lubin Chapter, proved to be very durable, because in the later period such violent and deep conflicts no longer occurred.
\end{abstract}

Keywords: monks, abbey, prepositure. 
